\title{
Is Trehalose a Precursor of Sulfated L-Galactan?
}

\author{
トレハロースは、硫酸化 L-ガラクタンの前駆体か？
}

\author{
Mourão, Paulo A. S., and Assreuy, Ana-Maria S. (1995) J. Biol. Chem., 270, 3132-3140
}

Key Words: biosynthesis, precursor, sulfated galactan, trehalose

Sulfated polysaccharides are components of proteoglycans in animal tissues, and are known as chondroitin sulfate, keratan sulfate, heparin sulfate, dermatan sulfate and so on. The biosynthesis of sulfated polysaccharides involves the formation of a polymer from sugar nucleotides by specific glycosyltransferase, epimerization on the nucleotide or polymer level by epimerase, deacetylation and sulfation by sulfotransferase. Thus, there is a complicated process in the biosynthesis of sulfated polysaccharides, and one which is highly organized with several kinds of enzyme.

According to the authors, "sulfated polysaccharides from different invertebrate tissues include several that are not found in vertebrates". In previous studies, the authors reported that the major fraction of polysaccharides in the tunic of the ascidian was a high molecular weight glycan composed mainly of sulfated galactose residues, which occurs exclusively in the L-enantiomeric form. These were the first reports of sulfated polysaccharides containing large amounts of L-galactose but no D-galactose. Furthermore, they showed that galactose in the high molecular weight fraction occurs mainly as $\alpha$-L-galactopyranoside, linked glycosidically through positions 1-4 and sulfated at position 3 and that the most effective precursor is Dglucose.

In this paper the authors investigated in detail the biosynthetic pathways of the sulfated L-galactan in the ascidian tunic. Based on their findings, they hypothesized that trehalose in the ascidian tunic may be a precursor of the sulfated Lgalactan. The change in radioactivity incorporated into the molecules of the ascidian tunic was examined by pulse labeling slices of tunic using D- $\left[{ }^{14} \mathrm{C}\right]$ glucose, then by chasing after removing the $\mathrm{D}-\left[{ }^{1+} \mathrm{C}\right] \mathrm{glucose}$ from the incubation medium. These pulse-chase experiments showed that the amount of ${ }^{14} \mathrm{C}$-labeled trehalose increased during the pulse period but decreased sharply during the chase period. In contrast, the amount of ${ }^{14} \mathrm{C}$ labeled sulfated polysaccharide increased during both periods. In addition, L-galactose was not detectable among the intermediates of the metabolic route. From these results the authors deduced that trehalose produced from D-glucose is a precursor of the polymer, and that epimerization of D-glucose into L-galactose occurs after the incorporation of D-glucose into the polymer. The epimerase involved in the epimerization of $\mathrm{D}$ -
硫酸化多糖は動物組織中のプロテオグリカンの構成成分と して知られており、例えばコンドロイチン硫酸、ケラタン硫 酸、ヘパラン硫酸、デルマタン硫酸などがある。その生合成に は、特異的な糖転移酵素による糖又クレオチドからのポリマー の形成、ヌクレオチドレベルまたはポリマーレベルにおける異 性化酵素による異性化、脱アセチル化、硫酸基転移酵素による 硫酸化が関係している。このように硫酸化多糖の合成には複雑 な過程が必要で、複数の酵素が高度に組織化されていると考え られている。種々の無春椎動物の組織には、春椎動物には見ら れない硫酸化多糖がいくつか存在する。

著者らは、以前の研究でホヤ被膜の硫酸化多糖は主に硫酸 化されたガラクトースを主構成成分とする高分子グリカンであ り、それらは全て L 体であるということを報告している。D-ガ ラクトースではなくL-ガラクトースが多量に含まれる硫酸化多 糖に関する報告はこれが最初である。さらに、高分子画分のガ ラクトースは主として1位と4 位でグリコシド結合し、3位が硫 酸化された $\alpha$-L-ガラクトピラノースとして存在していること、 硫酸化 L-ガラクタンの生合成のための最も効率の良い前駆体 は、D-グルコースであることを報告している。

ここに紹介する論文では、ホヤ被膜の硫酸化L-ガラクタン 生合成についての研究が詳しく述べられている。ここで得られ た結果から、著者らはトレハロースが硫酸化L-ガラクタンの前 駆体であるという仮説に至った。D- $\left[{ }^{[+C} \mathrm{C}\right]$ グルコースを添加した 培地中でホヤ被膜切片をインキュベーションし(パルス期)、次に D- $\left[{ }^{1+} \mathrm{C}\right]$ グルコースを含まない培地中でインキュベーションする こと(チェース期)によって組織中に取り込まれた放射活性の变化 を調べている。この手法を用いた実験で、トレハロースへの放 射活性の取り込みがパルス期に増加するがチェ一ス期に急速に 減少すること、対照的に硫酸化L-ガラクタンへの取り込みはパ ルスおよびチェース期共に増加することが示された。さらに、 代謝経路の中間体としてL-ガラクトースは検出されなかった。 これらの結果は、D-グルコースから生成したトレハロースを前 駆体としてポリマーが合成され、その後 L-ガラクトースへの異 性化が起こることを示唆している。また、D-グルコースの2、3 および 5 位の炭素に結合している水素原子は、D-グルコースか 
glucose into L-galactose was not an $\mathrm{NAD}^{+}$or $\mathrm{NADP}^{+}$-bound enzyme, because the hydrogen atoms at carbons 2,3 , and 5 of D-glucose were exchanged with the protons of water during this enzymatic conversion.

Trehalose is a nonreducing disaccharide widespread in nature and has been isolated from plants, algae, bacteria, fungi, yeasts, insects and invertebrates. In fungi and yeasts, trehalose appears to function as a source of reserve energy during periods of nonproliferation. In insects, it provides a source of energy for flight. It has also been reported that this sugar may function to protect the biological tissues of some plants and animals from damage due to desiccation and freezing. On the other hand, the only known enzymes related to trehalose are trehalase (EC 3.2.1.28), trehalose-phosphatase (EC 3.1.3.12), trehalose phosphorylase (EC 2.4.1.64) and trehalose phosphate synthase (EC 2.4.1.15). As stated in their paper, the utilization of trehalose as a donor substrate in polysaccharide synthesis is not known.

According to their hypothesis, trehalose is converted into the $1,4-\beta$-D-glucan, namely, cellulose. If cellulose or cellooligosaccharide is incorporated into the cells of the tunic, is sulfated L-galactan or L-galactooligosaccharide produced? To obtain more detailed information on this hypothesis that trehalose is a precusor of sulfated L-galactan, a cell-free system will have to be developed. To prove that this hypothesis is correct would mean the discovery of a new biosynthetic pathway of sulfated polysaccharides and of a new function of trehalose, which would then spur the discovery of new enzymes relating to trehalose.

\section{Reported by Nishimoto, $\mathrm{T}$., and Chaen, $\mathrm{H}$.}

Amase Institute, Hayashibara Biochemical Laboratories, Inc. Amase-minamimachi,

Okayama 700, Japan
らL-ガラクトースへの異性化される時に水のプロトンと交換さ れることから、異性化に関与している酵素、異性化酵素は $\mathrm{NAD}^{+}$またはNADP+結合型酵素ではないことが示された。

トレハロースは自然界に宅く分布した非還元性二糖で、植 物、藻類、細菌、カビ、酵母、昆虫、無脊椎動物から単離され ている。カビや酵母では、トレハロースは非増殖期における貯 蔵エネルキ一源と考えられている。昆虫では、飛行するための エネルキー源を供給している。また、ある種の動植物の組織を 乾燥や凍結から保護するために機能しているという報告もあ る。一方、トレハロースに関連した酵素としては、トレハラー ゼ(EC 3.2.1.28)、トレハロースホスファターゼ(EC 3.1.3.12)、ト レハロースホスホリラーゼ(EC 2.4.1.64)、トレハロースリン酸シ ンターゼ(EC 2.4.1.15)が知られているのみである。著者らも述べ ているように、トレハロースが多糖合成のための供与体となる という報告はない。

彼等の仮説によれば、トレハロースは 1 位と 4 位でグリコ シド結合したアーグルカン、すなわちセルロースに変換されるこ とになる。もし、セルロースやセロオリゴ糖を細胞中に取り込 ませることができれば、これらは硫酸化L-ガラクタンや硫酸化 L-ガラクトオリゴ糖に変換されるのであろうか。トレハロース が硫酸化L-ガラクタン生合成の前駆体であるというこの仮説に 関してさらに詳細な情報を得るためには、無細胞での合成系の 確立が必要である。もし、この仮説が証明されたならば、それ は硫酸化多糖の新しい生合成経路およびトレハロースの新しい 機能の発見を意味し、さらにはトレハロースに関連した新しい 酵素の発見に発展するであろう。

株式会社林原生物化学研究所・天瀬研究所 西本友之、茶圓 博人 